\title{
Public communication of science in Spain: a history yet to be written
}

\section{Lourdes López Pérez and María Dolores Olvera-Lobo}

\begin{abstract}
The history of public communication of science in Spain is yet to be written. Few academic studies exist that have tackled this subject. The political and economic history of the country have marked out the evolution of this discipline, which burst into the country at the end of the 20th century with the proliferation of initiatives such as the creation of science museums, the building of the Spanish Science Foundation and the development of a public Scientific Information service. Despite these efforts, the level of scientific culture for Spanish people is one of the lowest in Europe [OECD, 2016].
\end{abstract}

Keywords

Introduction
History of public communication of science

The history of public communication of science in Spain is yet to be written. The scarce scientific literature published in this area [González-Alcaide, Valderrama-Zurián and Aleixandre-Benavent, 2009] is also reflected in its historiographic treatment, as there are no compendiums covering the evolution of this discipline. It is therefore complicated to determine how and when it starts, and even establish a historical journey as, like the history of science, the history of communication has also been dominated by advancements and setbacks, as a result of the economic and political upheaval suffered by Spanish society since the 17th century. Some of the most renowned Spanish authors in the field of scientific journalism [Elías, 2001] place the starting point for public communication of Spanish science at the visit of the winner of the Nobel prize for Physics, Albert Einstein, to Spain in February 1923. In this way, we could say that this discipline started to arise almost three centuries after it did so in the other European countries. This situation is only understandable by going over the story of Spanish science marked by years of scarcity [Ferńandez-Rañada, 2003] and isolation [Sánchez Ron, 1999].

To witness a true boom in the public communication of science in Spain, it is necessary to wait until the end of the 1980s and the beginning of the 1990s, with the creation of the first permanent science sections in the most prominent national newspapers, the proliferation of interactive science museums and planetariums throughout the country, and the creation of institutions such as the The Spanish Foundation for Science and Technology. 
Timeline of communication public science

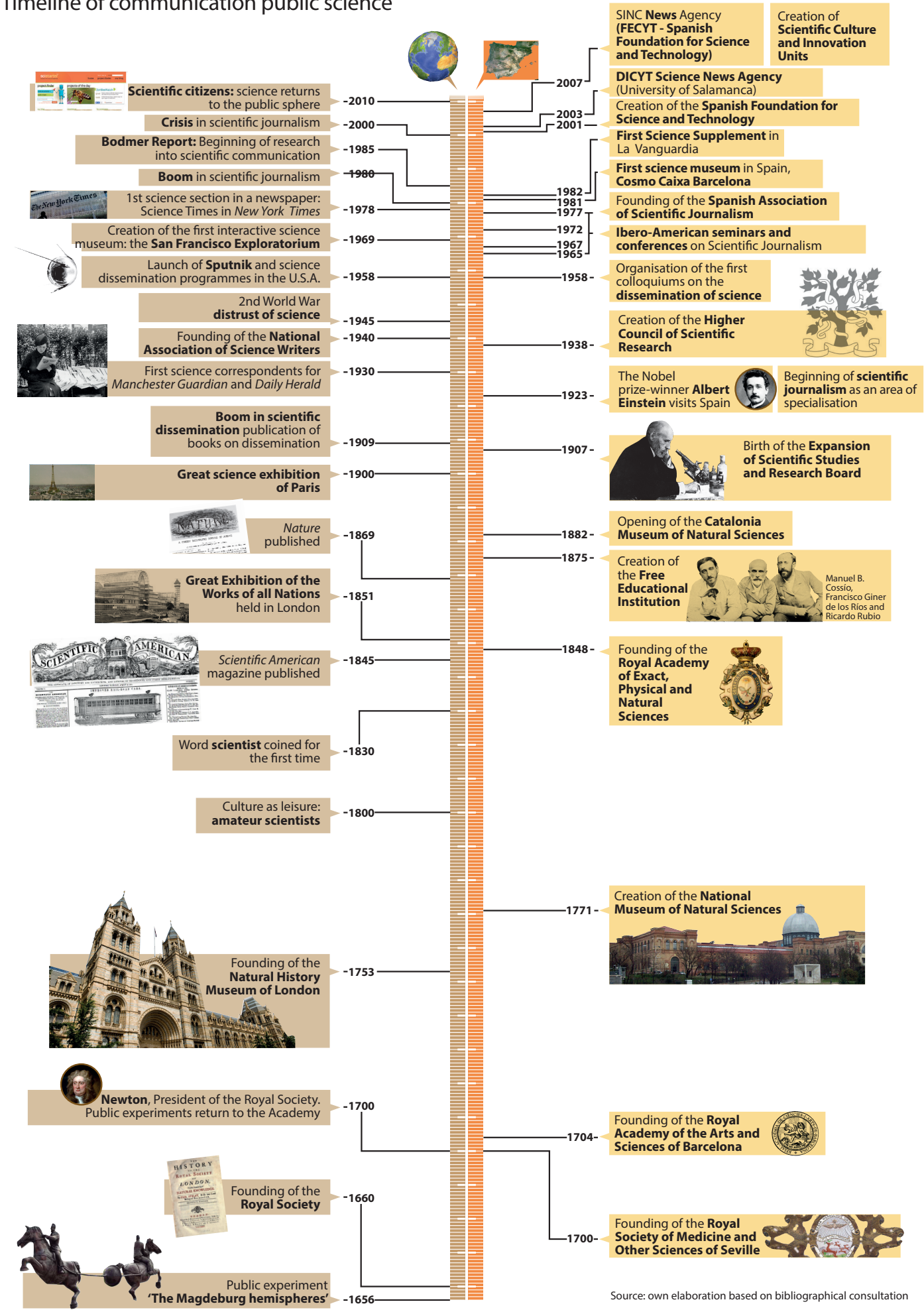

Figure 1. Timeline of communication public science. 
When did Spain miss the science train?
The 17th century constitutes a crucial era for science [Sánchez Ron, 1999]. Harvey demonstrated general blood circulation; Galileo published his revolutionary Dialoosoprai due massimisistema del mondo, tolemaico e copernicano; Newton composed his Philosophiae Naturalis Principia Mathematica and the first scientific societies were created: the Royal Society in London and the Academie Royale des Sciences in Paris. It was the century of scientific revolution. Those years saw the consolidating of modern science and the forging of the identity of today's European, with the development of critical thinking, public opinion and freedom of thought [Ferńandez-Rañada, 2003].

Spain remained isolated from European scientific currents and marginalised from the starting point of the scientific revolution [López Piñero, 1979; Sánchez Ron, 1999; Fernandez-Rañada, 2003]. It was only over the last few decades of the century that there was a fledgling rupture with traditional thought and its assumptions. A reformist movement arose, driven by those known as the Novatores, who raised explicit awareness of Spain's scientific backwardness and attempted to introduce the fundamentals of modern science.

Spanish scientific activity in that golden century was basically the importation of that produced in other countries.

In a sense, we can say that these Novators were also pioneers in the communication of science, because one of the ways they found to break with the traditional system and disseminate learned ideas was the organisation of debates and meetings for sharing and enjoying knowledge. Zaragoza, Barcelona, Valencia and Seville were some of the nerve centres of these scientific encounters, supported by the need to share knowledge. Notwithstanding, this sharing was focused on a few, the minority cultured class in the Spain of the era.

The drive from the novators for the scientific regeneration of the country came about at the start of the 18th century with the creation of the Royal Society of Medicine and Other Sciences of Seville (1700), and the Royal Academy of the Arts and Sciences of Barcelona (1704). Almost at the end of the century, Spain added itself to the European wave of science museum creation with the opening of the National Museum of Natural Sciences. In its beginnings, around 1772, it is called Real Cabinet of Natural History.

This rise, however, would be stopped during the 18th and 19th centuries and did not reappear until the middle of the 19th century with the creation of the Royal Academy of Exact, Physical and Natural Sciences.

We must wait until the last two decades of the century to be able to witness another moment of renovation in the history of Spanish science and its popularization. 1875 saw the creation of the Free Teaching Institute, which meant a boost for scientific development. With its constitution, exposure returned to the stage as we can read in the first point of the general rules of the institution: "Its aim is to found a free institution dedicated to the cultivation and promotion of science in its diverse forms" [Jiménez-Landi, 1996]. Some years later, in 1882, the Museum of Natural Sciences of Catalonia opened.

But the authentic regeneration of Spanish science and the first steps of its communication arrived with the Junta de Ampliación de Estudios e 
Investigaciones Científicas (JAE). In 1907 this institution, inspired by the Free Teaching Institute, was founded. Under the presidency of the Nobel prize winner, Santiago Ramón y Cajal, some of the most eminent scientists in Spain such as Blas Cabrera, Miguel Catalán, Enrique Moles, Juan Negrín, Arturo Duperier and Severo Ochoa, worked in the JAE.

Many of them, like Santiago Ramón y Cajal himself, became aware of the importance of the communication of scientific knowledge for boosting the regeneration of Spain. They organised conferences and sessions open to the public. Amongst the efforts towards dissemination was the season series of lectures that the winner of the Nobel Prize in Physics, Albert Einstein, gave in 1923.

\section{Scientific journalism evolution}

From a journalistic point of view, the lectures that the winner of the Nobel Prize in Physics, Albert Einstein, gave in 1923, is rated as the beginning of informative specialisation in science [Elías, 2001]. The lectures given by Einstein were covered by the entire press. His visit took up the front pages in national newspapers and the masses "followed Einstein more than the bullfighters" [Elías, 2001] (Figure 2).

Einstein's visit to Spain and its communication had such an impact that, according to authors such as Elías [2001], it led to a stimulation of studies of exact sciences in the country, and the introduction of more science in engineering.

This blossoming scarcely lasted three decades, as the Civil War put another stop to scientific development, and the subsequent establishment of the Dictatorship isolated Spain from the rest of Europe once more.

One of the main consequences of the new political regime was the disappearance of the Board for the Expansion of Scientific Studies and Research.

In its place, on 19 May 1938, the Higher Council of Scientific Research was created. The brain drain, the disappearance of aid for expanding studies beyond national boundaries and, in general, the economic, political and social crisis the country went through during the period put a complete stop to the development of science and, as a result, its communication.

Spanish science did not recover until the end of the 60 s and the beginning of the 70 s.

In parallel, a fledgling movement began for the development of the public communication of science with the organisation of colloquiums on the dissemination of science (Madrid, 1958 and 1965), Ibero-American seminars on scientific journalism (Madrid 1967, La Coruña, 1972) and the II Ibero-American Scientific Journalism Congress (Madrid, 1977).

The creation of the Spanish Association of Scientific Journalism in 1970 is also a reflection of this concern for bringing science closer to society in the last years of the dictatorship [Calvo Hernando, 2003].

In this decade, specifically in 1976, Journal Investigación y Ciencia was the first Spanish printed medium dedicated to communicating scientific breakthroughs 


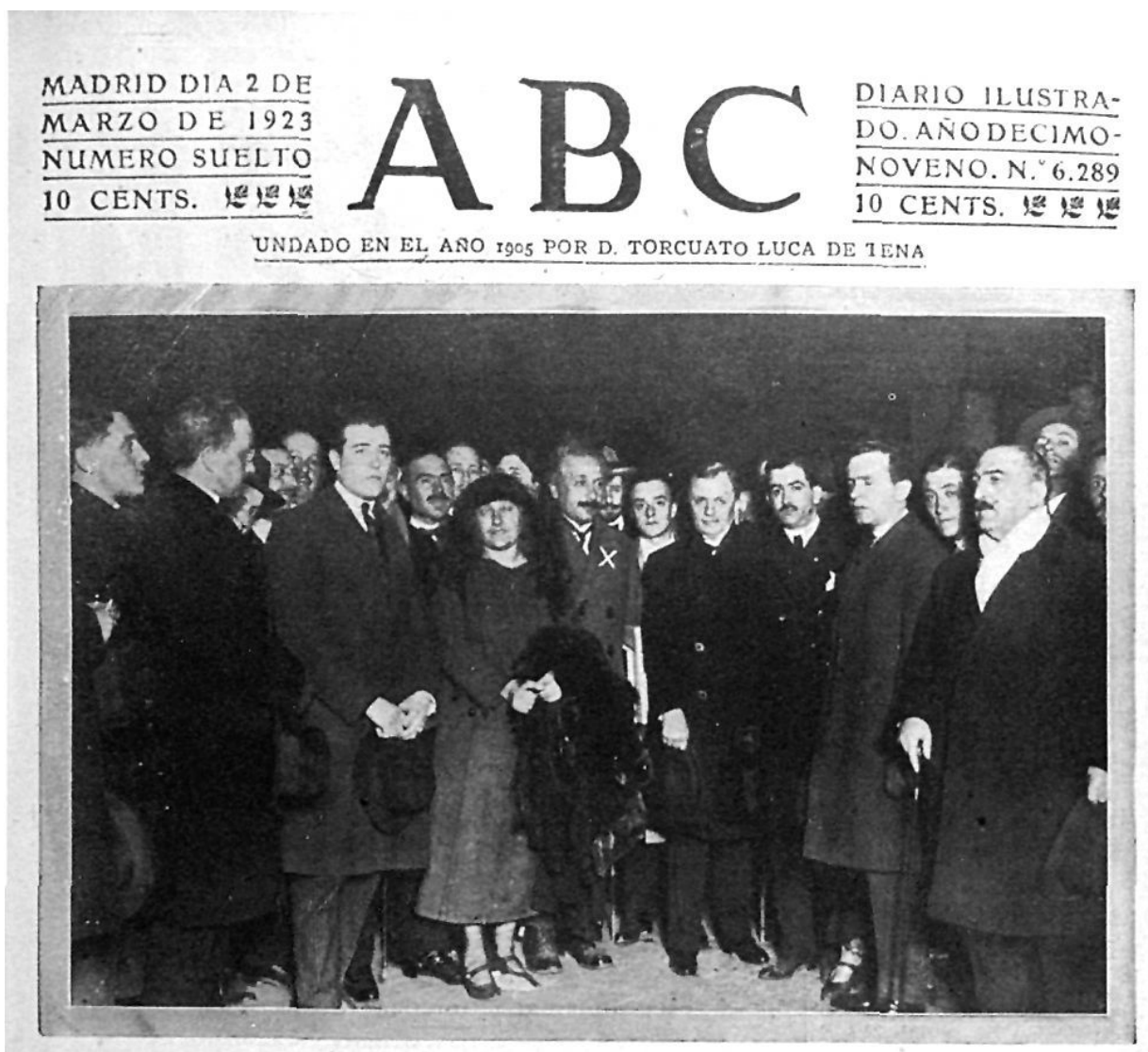

UNDADO EN EL, ANO TgO5 POR D. TORCUATO LUCA DE TENA

MADRID. EN LA ESTACION DEL MEDIODIA

LLEGADA DEL INSTGNE PROFESOR DOCTOR EINSTEIN (x) AYER NOCHE. (FOTO LARREGLA)

EN EL CENTENARIO | tativos dal siglo xix. Pero tiene sobré sus $\mid$ me tangcre, he ahi cuarto hace falta exiDE RENAN

Comio están en plena "unín sagrada",
los francerses han depuesto tambićn ahorá

con ta mejor pompa apologetica el certe-

nario de la venida al mundo de Ernesto

Perán. Pocos escritores de los áltimos tiem-

pcs han suscitado como él tantas disputas,
tantos rencores y alabarzas. Su nombre b.

tantos rencores $y$ alabarzas. Su nombre ha
sito mis de uma vez bandera de combate.

S I cmago el patriotismo exaltado de los

franceses modernos no ha consentido que
cte centerario se convierta en una luc

d- doctrinas. La Francia tiene sed de glo.

T. Barrés se prestare diaer la nás pro.

da apotcosis,
Se ptede situar a Renán entre los escri-

res profurdamente caracteristicos de e

tios y continia en nuestros dias Pepre

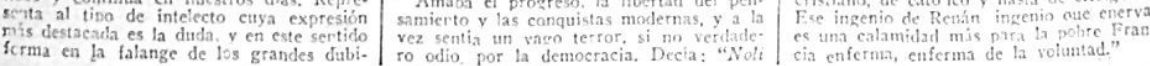

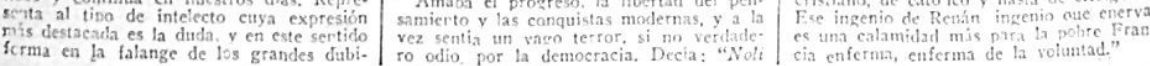

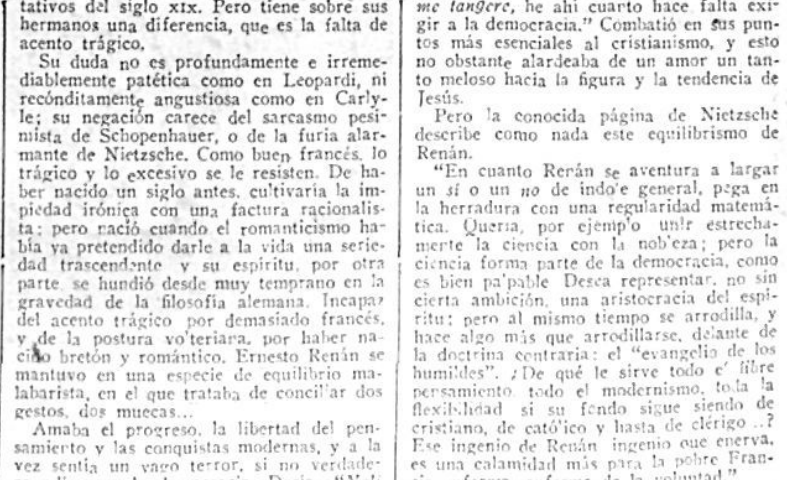

Figure 2. Front page of the newspaper ABC, 2 March 1923.

[Investigación y Ciencia, 2016]. Following this, in 1981, the popular magazine Muy Interesante appeared [Muy Interesante, 2011].

Spanish TV and radio was starting to pay attention to science, producing popular science programmes such as 'La Aventura de la vida' on Radio Nacional de España and 'El hombre y la Tierra' on Televisión Española [Seara, 2016].

In the 1980s the public communication of science in Spain experienced a boom with the proliferation of the aforementioned media and programmes and with the integration of science in the journalistic agenda through weekly sections and supplements between 1982 and 1993. The first newspaper to have a weekly science 
supplement was La Vanguardia in 1982 (Figure 3) [de Semir and Revuelta, 2002]. El País published a section dedicated to scientific information in 1980 [Alarcó and Acirón, 1999]. ABC followed El País in creating a science section and El Mundo had a permanent daily section in its printed edition from 2002.

Other examples of scientific communication on Radio and TV are TV3's 'Que Qui Com', created in 2006, and TVE's 'Tres14' in 2007 [Montserrat Rosell, 2016].

Journalism was once more the spearhead of the development of the public communication of science in Spain, although it would quickly face the problems that remain unsolved almost thirty years later. The lack of a popular clamour for scientific research, the disinterest of the communications media and the difficulty of access to information sources, the scarce concern of scientific organisations for disseminating science and the lack of scientific awareness on the part of society are some of the biggest of these [Calvo Hernando, 2002].

Now, thanks to the Internet, this situation is changing, with initiatives such as Naukas (http: / / naukas.com) and AgenciaSinc (http:/ / www.agenciasinc.es) (online channels specialising in scientific information), Materia (Scientific section in elpais.es) (http:/ / esmateria.com) and blogs created by scientists (http:/ / www.csic.es/blogs) [Fernández de Lis, 2016]. In fact, many academics, like Antonio Martínez Ron [2016], claim that the future of science communication is collaborative.

Museums and science centers evolution
Museums and science centers have been an important role in Spanish science communication history. The first interactive science museums and planetariums were appearing in Spain, such as the Cosmocaixa (Barcelona) in 1980, the Casa de las Ciencias (La Coruña) in 1985 and the Planetario de Madrid (Madrid) in 1986. They were followed in the 90s and the first few years like Pamplonetario (Navarra), in 1993 or Parque de las Ciencias (Granada) in 1995 of the 2000s by over 40 science centres and planetariums distributed across the country [Páramo, 1999; Fundación Española para la Ciencia y la Tecnología, 2017a].

The interactive science museums became a fundamental tool for bringing scientific development closer to society in an understandable and convenient way, and in a medium for scientific dissemination in order to increase the level of scientific culture in Spanish society.

They also focused on the need to create a theoretical corpus to support this discipline, with the organisation of conferences on the social communication of science. The first was held in Parque de las Ciencias of Granada, where attendees signed the Granada Declaration [Parque de las Ciencias, 1999]. In this document journalists, museologists, publicists, scientists and teachers established the courses of direction the public communication of science should follow. Amongst the precepts integrated into this declaration they highlighted the need to bring the scientific debate outside the laboratories, involving society therein; the urgent need to consolidate the public communication of science as a discipline not merely subject to the personal will of the researcher or journalistic newsworthiness; the obligation on the part of the communications media to give better coverage to 


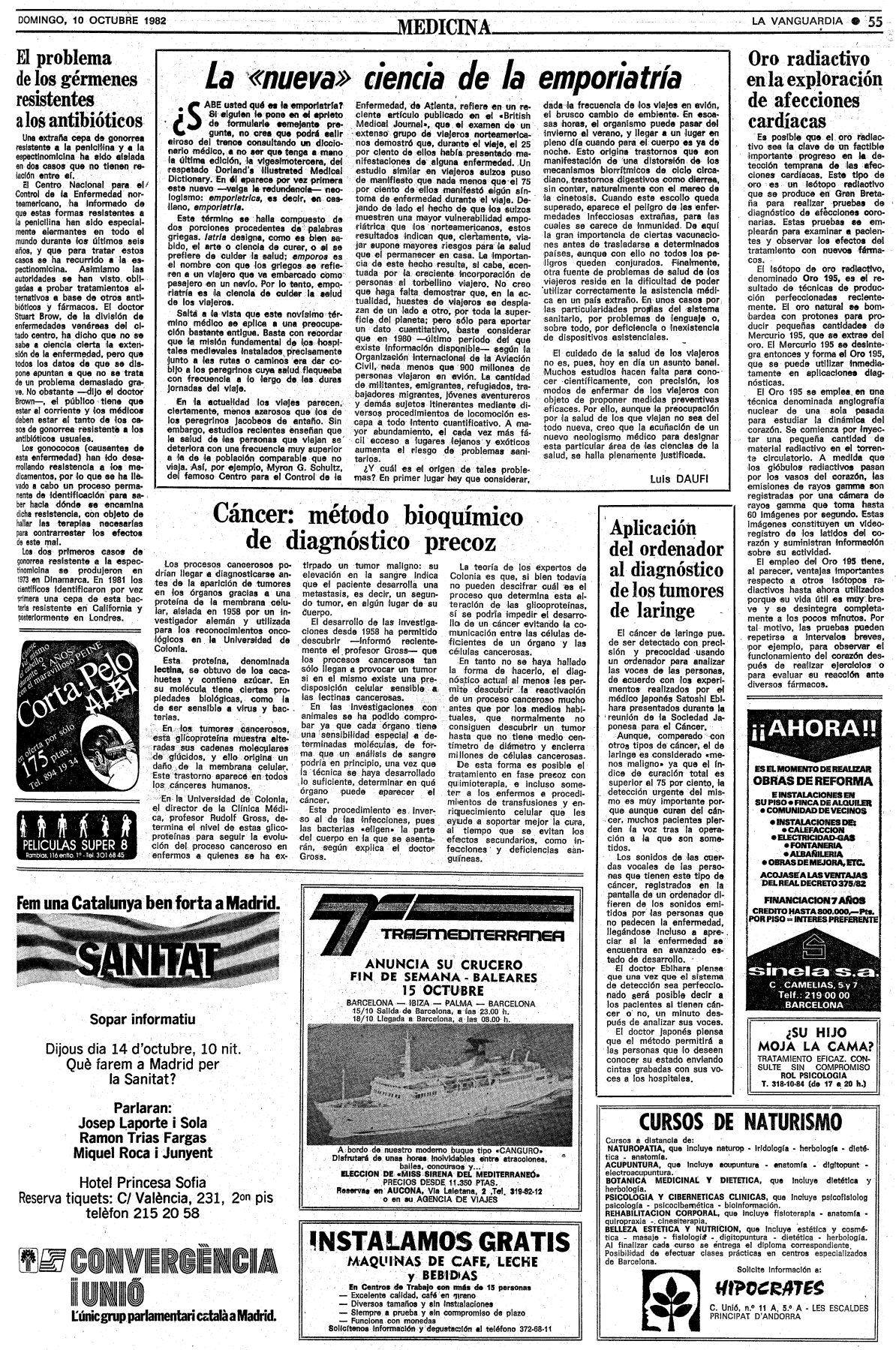

Figure 3. Science Supplement from La Vanguardia, the first in Spain.

scientific information, and the direct implication of researchers in the communication of their results to the public.

After this conference, another four were held in Valencia (2001), A Coruña (2005), Madrid (2007) and Pamplona (2010). It is also important to mention two International Meetings on Public Communication, organized by the International 
Network on Public Communication of Science and Technology, held in Madrid in 1991 and in Barcelona in 2004 [Cheng et al., 2008].

There are currently close to 33 science centers, museums, aquariums and botanical gardens [Fundación Española para la Ciencia y la Tecnología, 2017a] and they suppose a fundamental complement for the school curriculum. Their role is, on the whole, educational, and they deal with the dissemination of the general scientific bases; however, in general, they are not the setting for the presentation of scientific results to society.

Their role is unquestionable nowadays as they provide, in many cases, citizens' first encounter with science [Núñez, 1997].

Training scientific communication in university
The role of the

\section{Spanish}

Government and the Fundación

Española para la Ciencia y la Tecnología
The boost that Spanish science communication experienced in the 90s was also manifested in its transference to the academic sphere, with the offer of postgraduate courses in the Public Communication of Science from different universities. The first was Pompeu Fabra University, whose Master's in Scientific, Medical and Environmental Communication began in 1995 (http:/ / www.barcelonaschoolofmanagement.upf.edu/es/master-encomunicacion-cientifica-medica-y-ambiental). Another pioneer was the University of Salamanca whose Master's in Social Studies of Science and Technology began in 1998 (http: / / mastercts.usal.es). In the first decade of 2000 other universities such as the University of Valencia, the Carlos III University of Madrid, the National Distance Learning University (UNED), University of Oviedo, Autonomous University of Madrid, Autonomous University of Barcelona, Complutense University of Madrid and the University of Granada have organized Master's degrees and postgraduate studies in science communication.

There was also a proliferation of professorships in dissemination such as Public Communication of Science at the University of Valencia (2002); Scientific Dissemination at the University of Valladolid (2005); Scientific Culture at the University of Girona (2008); Scientific Dissemination at the University of Zaragoza (2009) and Scientific Culture at the University of the Basque Country (2010)

Another important moment in the history of Spanish science communication was in 2001 with the creation of the Spanish Foundation of Science and Technology. Created by the Spanish government, this institution was a good example of Spanish society realizing the importance of science dissemination. Two of the main aims of this institution were to increase society's interest in science and technology and communicate scientific research funded with public resources.

With the beginning of the 21st century, Spain became aware of the importance of the increase in culture and scientific vocations for the development and maintenance of a system of research, development and innovation in the country. The 'Week of Science' Science Fairs were organized in different cities to engage the public in the topic. Equally, different institutions set up programmes specialising in the public communication of science for journalists, such as Andalucía Investiga in Andalusia, Novatores in Castilla y León and Aragón Investiga in Aragón. 
The strategies for extending the relationship between science and society were reinforced since the creation of the FECYT. A year later, the foundation set in motion scientific studies in the country to discover what perception citizens had of science. Since then, eight surveys have been carried out on the Social Perception of Science and Technology [Fundación Española para la Ciencia y la Tecnología, 2017b]. Previously other institutions such as Pompeu Fabra University and the BBVA Foundation had carried out studies on perception in Spain [Miller, Pardo and Niwa, 1997; Ribas and Cáceres, 1997].

It is worth highlighting the economic boost of the annual public announcement for the Promotion of Scientific Culture promoted by FECYT. It encourages the developing of science communication projects and it is currently one of the most important financial supports that exists in this area.

In 2007 Spain celebrated the Year of Science (an initiative of Barcelona City Council) and within this anniversary initiatives were born for helping research centres to open the doors of investigation to the public.

2007 also saw the creation of the SINC Science News Agency, dependent on the Spanish Foundation for Science and Technology and dedicated to the dissemination of scientific results. Its main objective is to act as an intermediary between scientists and journalists and increase coverage of scientific information in the national media. It only exists in online form and publishes news available to all publics, although it has a subscription system exclusively for journalism professionals [Servicio de informacion y noticias científicas, 2015]. There was a precursor of this agency, named DICYT, that was created by the Salamanca University in 2003 and it was focused on regional information [Quintanilla et al., 2001].

In this context, the Scientific Culture and Innovation Units were created with the aim of improving and increasing citizens' scientific training, culture and knowledge [Fundación Española para la Ciencia y la Tecnología, 2017c].

At present there are 79 Scientific Culture and Innovation Units in Spain [Fundación Española para la Ciencia y la Tecnología, 2017c] integrated into public centres or entities in the R\&D+i (Research \& Development + Innovation) system, and in non-profit private entities in the $\mathrm{R} \& \mathrm{D}+\mathrm{i}$ system. Amongst the main functions of these units are the communication of $R \& D+i$ results, the general dissemination of scientific and technological knowledge, the guidance and training of research personnel in the dissemination of science, and the development of technology and research for $\mathrm{R} \& \mathrm{D}+\mathrm{i}$ dissemination processes.

Despite efforts towards dissemination in recent decades, Spain is still one of the European countries with the least scientific culture [OECD, 2016]. Perhaps the moment has arrived for scientists to once again occupy the public sphere and communicate the results of their work to society. The economic crisis and the cuts experienced by Spanish research in recent years are seriously affecting resources directed at $R \& D+i$. Only the public can reverse this situation with its voice and decisions, but in order to do so it must be informed and feel part of the scientific process. Is the second decade of the 21st century the moment to demystify science for it to once again take up a place in society? The consolidation of the Internet as 
one of the main means of communication allow conversation as equals between scientists and the public. This is a situation that has already spread in countries that are pioneers in the public communication of science, and Spain should not be left on the sidelines.

To promote a real participation and implication of the public in the scientific process, it is essential to consolidate Spain in the Public Communication of Science as a scientific discipline that tackles the study of this area from all perspectives, history, participation, perception, etc.

\section{References}

Alarcó, A. and Acirón, R. (1999). ‘Periodismo científico en la prensa diaria. Aspectos de biomedicina'. Ph.D. Thesis. Universidad de la Laguna, Islas Canarias, Spain. URL: ftp://tesis.bbtk.ull.es/ccssyhum/cs80.pdf (visited on 4th September 2015).

Calvo Hernando, M. (2002). 'El periodismo científico, reto de las sociedades del siglo XXI'. Comunicar (19), pp. 15-18. ISSN: 1134-3478.

URL: https://dialnet . unirioja.es/servlet/articulo?codigo=271749.

- (2003). Divulgacioń y periodismo científico: entre la claridad y la exactitud. Mexico: Direccioń General de Divulgacioń de la Ciencia, Universidad Nacional Autońoma de Mex́ico. ISBN: 970-32-1057-0.

Cheng, D., Claessens, M., Gascoigne, T., Metcalfe, J., Schiele, B. and Shi, S., eds. (2008). Communicating Science in Social Contexts. New models, new practices. Dordrecht, Netherlands: Springer. DOI: 10.1007/978-1-4020-8598-7.

de Semir, V. and Revuelta, G. (2002). 'Ciencia y medicina en La Vanguardia y The New York Times. Un capítulo de la historia del periodismo científico'. Quark 26, pp. 68-81. URL: http://quark. prbb.org/26/026068.htm.

Elías, C. J. (2001). ‘Influencia de la historia de España (siglos XIX y XX) en el periodismo especializado en ciencia. Siglo XIX: La vuelta al absolutismo y la esperanza de la Institución Libre de Enseñanza'. Revista Latina de Comunicación Social 39. URL: http: //www . redalyc . org/articulo. oa?id=81939403.

Fernández de Lis, P. (2016). 'Retos de la Comunicación Científica'. Investigación y Ciencia 481, p. 28.

URL: http://www. investigacionyciencia.es/revistas/investigacion-y-ci encia/numero/481/retos-de-la-comunicacin-cientfica-14563.

Ferńandez-Rañada, A. (2003). Los muchos rostros de la ciencia. Mexico: La ciencia/192 para todos. ISBN: 9789681668693.

Fundación Española para la Ciencia y la Tecnología (2017a). Museos de Ciencia. URL: https://www.fecyt.es/es/museos-de-ciencia (visited on 21st June 2017).

- (2017b). Percepción Social de la Ciencia y la Tecnología 2016. Madrid, Spain. URL: https://www.fecyt.es/es/noticia/crece-el-interes-de-las-mujeres -por-la-ciencia-y-la-tecnologia.

- (2017c). Unidades de Cultura Científica. URL: https://www . fecyt.es/es/info/que-son (visited on 21st June 2017).

González-Alcaide, G., Valderrama-Zurián, J. C. and Aleixandre-Benavent, R. (2009). 'La investigación teórica sobre la divulgación de la ciencia en España: situación actual y retos para el futuro'. ARBOR Ciencia, pensamiento y cultura 185 (738), pp. 861-869. DOI: 10.3989/arbor . 2009.738n1058.

Investigación y Ciencia (2016). Investigacioń y Ciencia cumple cuarenta años. URL: http://www . investigacionyciencia.es/files/26024.pdf. 
Jiménez-Landi, A. (1996). La Institucioń de Libre Enseñanza. Vol. 4. Madrid, Spain: Editorial Complutense. ISBN: 84-89365-57-1.

López Piñero, J. M. (1979). Ciencia y técnica en la sociedad española de los siglos XVI y XVII. Barcelona, Spain: Labor. ISBN: 84-335-1723-6.

URL: https://dialnet.unirioja.es/servlet/libro?codigo $=57882$.

Martínez Ron, A. (2016). 'El futuro de la divulgación científica es colaborativo'. Investigación y Ciencia 481, p. 32. URL: http://www . investigacionyciencia.es /revistas/investigacion-y-ciencia/especial-40-aniversario-682/el-fu turo-de-la-divulgacin-cientfica-es-colaborativo-14569.

Miller, J. D., Pardo, R. and Niwa, F. (1997). Public perceptions of science and technology: a comparative study of the European Union, the United States, Japan, and Canada. Bilbao, Spain: Fundación BBVA and Chicago Academy of Sciences.

Montserrat Rosell, A. (2016). 'El lento despertar de la cultura científica en los medios'. Investigación y Ciencia 481, p. 31. URL: http://www. investigacionycie ncia.es/revistas/investigacion-y-ciencia/numero/481/el-lento-desper tar-de-la-cultura-cientfica-en-los-medios-14565.

Muy Interesante (2011). Muy Interesante cumple 30 años. URL: http: //www . muyinter esante.es/ciencia/articulo/muy-interesante-cumple-30-anos.

Núñez, R. (1997). 'Los centros de divulgacioń científica en España: Panorama a finales del siglo XX'. Quark 8, pp. 29-38.

URL: http://quark.prbb.org/8/articulos.htm\#articulo2.

OECD (2016). PISA 2015 Assessment and Analytical Framework. Reading, Mathematic and Financial Literacy. OECD Publishing. DOI: $10.1787 / 9789264255425$-en.

Páramo, E. (1999). Comunicar la Ciencia en el Siglo XXI. Granada, Spain: Proyecto Sur Ediciones S. L. ISBN: 84-930639-2-4.

Parque de las Ciencias (1999). Declaracion de Granada. URL: http://www.parqueciencias.com/parqueciencias/quienes_somos/decl araciones/declaracion-granada.html (visited on 17th October 2016).

Quintanilla, M. A. et al. (2001). 'Science, technology and society: training the scientific communication professional in Spain and Latin America from an integral perspective'. In: 6th International Conference on Public Communication of Science \& Technology. (Geneve, Switzerland, 1st-3rd February 2001).

Ribas, C. and Cáceres, J. (1997). 'Perceptions of science in Catalan society'. Public Understanding of Science 6 (2), pp. 143-166. DOI: 10.1088/0963-6625/6/2/003.

Sánchez Ron, J. M. (1999). Cincel, martillo y piedra: historia de la ciencia en España (siglos XIX y XX). Madrid, Spain: Taurus.

Seara, M. (2016). 'Comunicar ciencia en la ciberradio'. Investigación y ciencia 481, p. 29. URL: http://www. investigacionyciencia.es/revistas/investigacion -y-ciencia/numero/481/comunicar-ciencia-en-la-ciberradio-14564.

Servicio de informacioń y noticias científicas (2015). SINC. La ciencia es noticia. URL: http://www . agenciasinc. es (visited on 10th July 2015). 
Lourdes López is PhD in Social Sciences and she has has graduated in Communication Science. Also, she has obtained a Master degree in Science Information and Communication at the University of Granada, Spain and one in Marketing and Commercial Management at ESIC Business School. Her professional career has developed within the area of Science Communication, as a conference speaker, a teacher, and author of a number of articles and book chapters. Ph.: (+34)652302109. E-mail: lourdes.lpez@gmail.com.

María Dolores Olvera-Lobo has graduated in Documentation Studies and is currently Full Professor of Information and Communication at the University of Granada, Spain. She is a member of the Scimago Group of the Spanish National Research Council (CSIC, Madrid). Both as an author and co-author, she has published books, essays and tens of articles in national and international journals with a certified quality index (JCR, SJR, RESH). E-mail: molvera@ugr.es.

\section{How to cite}

López Pérez, L. and Olvera-Lobo, M. D. (2017). 'Public communication of science in Spain: a history yet to be written'. JCOM 16(03), Y02. 